\title{
ADAPTATION AND VALIDATION OF THE PSYCHOLOGICAL CAPITAL QUESTIONNAIRE (PCQ) IN ARMENIAN LANGUAGE (A PILOT STUDY)
}

\author{
Voskanyan K. V., Papoyan S. A., Manukyan M. A., Hovsepyan N. S. (Yerevan \\ State University, Yerevan, Armenia) \\ voskanyankarlen@gmail.com, seda.papoyan@ysu.am, \\ mariam.manukyan9@ysumail.am,hovsepyan_narek@yahoo.com \\ 乙tinцmјшgर्umu uर्रu. 30.07.2021 \\ 9pmpunuर्या mर्रu. 10.08.2021

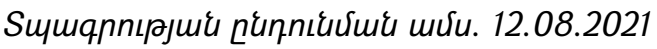

The article represents the main peculiarities of the process of PCQ (Psychological Capital Questionnaire) adaptation. A pilot study is performed to test the reliability and validity of Psychological Capital Questionnaire (PCQ) on the Armenian population. Psychological Capital (PsyCap) is a personal resource, which is linked with positive individual and organizational outcomes (performance, well-being, attitudes, etc). The study tested the validity between PsyCap and other constructs, such as Big Five personality traits, self-regulation (V. Morosanova), success motivation (T. Ehlers) and system of values (Schwartz). The components of PCQ were examined using correlation analysis on a sample Armenian employee. The results show that the Armenian version of the Psychological Capital Questionnaire is a reliable and valid tool and as a practical implication, PCQ is reliable to be used in the Armenian organizational context.

Keywords: psychological capital, adaptation, validation, correlation, Armenian sample.

DOI: https://doi.org/10.46991/SBMP/2021.4.2.365

Psychological capital (PsyCap) was in the center of attention since the movement of positive psychology. Extending new findings to the work place, Fred Luthans identified psychological constructs (i.e. self-efficacy, hope, optimism, and resilience), which met the criteria of being positive, based on theory and research. This construct was developed to provide practitioners with a new framework to ensure a sustainable competitive advantage via human resources [2]. The actuality of PsyCap assessment is due to its role in the resource system which is required for organizations of all types seeking sustainable growth and competitive advantage. There is a lack of assessing scales regarding capital in Armenia. Other types of capital include human capital, social capital, and economic capital [3]. 
The PCQ consists of four scales. Higher scores correspond to greater psychological capital abilities. The sum of PCQ scales is the indicator of Psychological Capilal.

Hope: an individual's ability to persevere towards goals and redirect paths to goals in order to succeed.

Efficacy: an individual's ability to have confidence to take on and put in the necessary effort to succeed at challenging tasks.

Resilience: an individual's ability to sustain and bounce back when beset by problems and adversity to attain success.

Optimism: an individual's ability to make a positive attribution and expectation about succeeding now and in the future [5; 7].

PsyCap is shown to be associated with desirable employee attitudes, such as staying intentions, job satisfaction and commitment. Employees high in PsyCap are found to be more empowered, which subsequently leads to less turnover intentions, and the reduction of absenteeism. Furthermore, individuals high in PsyCap perform better than those low in PsyCap since they can draw upon more resources to pursue goals. Most importantly, PsyCap is shown to be developable through training interventions, which makes it a useful and tangible construct actually able to influence individuals and even whole organizations in a positive way [2].

As we can see above PsyCap is associated with concepts such as job satisfaction, productivity, and motivation. Job satisfaction is a key factor in the modern managerial mentality, which express positive expectations and employee attitudes towards their work. In addition, the value of job satisfaction implies positive and optimistic emotions and thoughts about job [1].

The group of 6 experts conducted the process of translation. Firstly, the source text was translated Armenian (6 examples), then a different translator re-translated the instrument into the source language (English). The original and the twicetranslated instruments were then compared for commonality. If the match was deemed adequate, the target was adopted to use. If deemed unacceptable, then changes were made until the translated version is acceptable [4].

The study: Sample consisted of a total of 75 participants, from which 51 were valid (46 female, 5 male) between 18-60 years (Mage $=28.35$, SD $=9.8$ ). Participants were recruited by publishing the link to the survey in several social media groups. The survey was conducted in Armenian.

The 4 main tests were selected to conduct the correlation between the scales in order to discover the validity of PCQ:

1. The Big Five personality traits inventory (Arm.): for example, in our opinion the scale extraversion is considered to correlate positively with "optimism" of PCQ (similarly-conscientiousness with efficacy, etc.) 
2. Questionnaire: The individual style of self-regulation (V. Morosanova - Arm.): the main consideration that the scale will positively correlate with the scale hope [6].

3. The Portrait Values Questionnaire (PVQ - Arm.): the positive correlation was expected with many scales of terminal values.

4. The questionnaire "motivation for success" (Ehlers T.- Arm): the aim was to indicate the link between all components of PCQ.

The results: The inter-scale correlation analysis $(I B M \otimes S P S S \circledR-23)$ showed a high link between the PCQ scales: Spearman's rho (sig 2-tailed) with psycap scale (sum of all scales) for self-efficacy $=.806^{* *}$, hope $=.817^{* *}$, resilience $=.819^{* *}$, optimism $=.684^{* *}$. Correlation is significant at the 0.01 level (2-tailed). It indicates the high inner validity of the questionnaire.

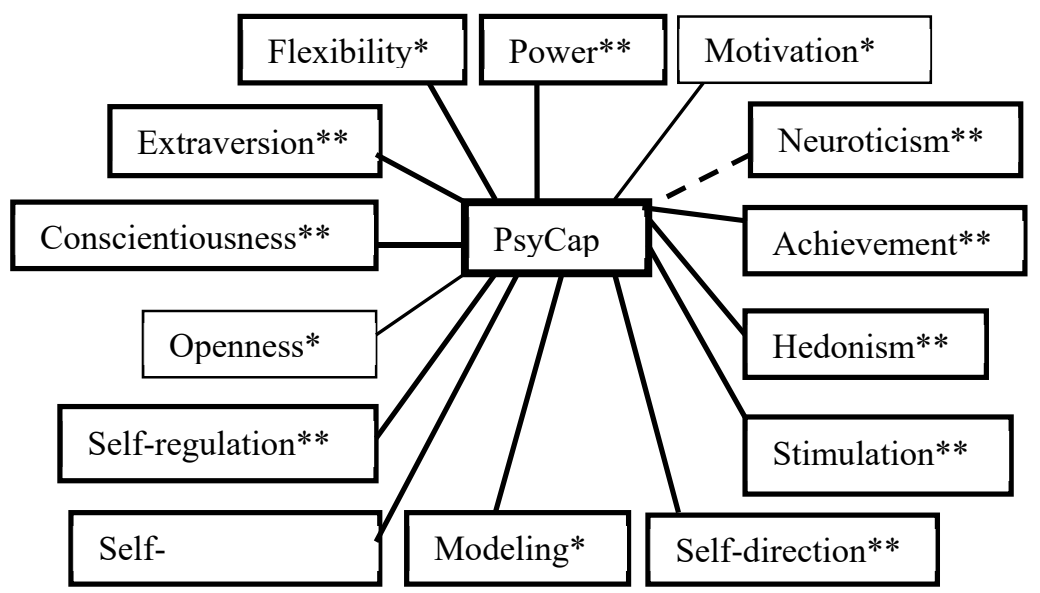

Figure 1. The visual analysis of correlation between PsyCap and other scales (bold-** significance level=0.01, pecked line-negative correlation)

The figure shows that PsyCap has high correlation level with 14 of 24 scales, which means that the translation and adaptation was successful and has high validity of usage.

The results of correlation between all 5 inventories $\left({ }^{*}\right.$ significance level $=0.01$, ${ }^{*}$ significance level=0.05) are shown in 2 lists:

\section{Positive correlations}

Self-efficacy: $\quad$ extraversion $\left(r=, 465^{* *}\right), \quad$ self-regulation $\left(r=, 462^{* *}\right)$, conscientiousness $\left(r=, 421^{* *}\right), \quad$ flexibility $\left(r=, 478^{* *}\right)$, modeling $\left(r=, 529^{* *}\right)$, universalism $\left(r=, 366^{* *}\right), \quad$ self-direction $\left(r=, 581^{* *}\right), \quad$ stimulation $\left(r=, 416^{* *}\right)$, hedonism $\left(r=, 526^{* *}\right), \quad$ achievement $\left(=, 568^{* *}\right), \quad \operatorname{power}\left(r=, 475^{* *}\right)$, motivation $\left(r=, 427^{* *}\right)$. 
Hope: extraversion $\left(r=, 459^{* *}\right)$, self-regulation $\left(r=, 462^{* *}\right)$, conscientiousness $\left(r=, 332^{* *}\right)$, self-sufficiency $\left(r=, 321^{*}\right)$, flexibility $\left(r=, 347^{*}\right)$, modeling $\left(r=, 361^{* *}\right)$, selfdirection $\left(r=, 385^{* *}\right)$, stimulation $\left(r=, 397^{* *}\right)$, hedonism $\left(r=, 357^{*}\right)$, achievement $\left(=, 353^{*}\right)$, power $\left(r=, 313^{*}\right)$.

Resilience: extraversion $\left(r=, 573^{* *}\right)$, aggreeableness $\left(r=, 310^{*}\right)$ selfregulation $\left(r=, 408^{* *}\right)$, Conscientiousness $\left(r=, 319^{*}\right)$, flexibility $\left(r=, 605^{* *}\right)$, universalism $\left(r=, 287^{*}\right)$, self-direction $\left(r=, 633^{* *}\right)$, stimulation $\left(r=, 574^{* *}\right)$, achievement $\left(=, 418^{* *}\right)$.

Optimism: flexibility $\left(r=, 307^{*}\right)$, self-direction $\left(r=, 320^{*}\right)$, stimulation $\left(r=, 321^{*}\right)$, hedonism $\left(r=, 301^{*}\right)$, achievement $\left(r=, 455^{* *}\right)$.

NEGATIVE CORRELATIONS

Self-efficacy: Neuroticism $\left(r=-, 321^{*}\right)$

Resilience: Neuroticism $\left(r=-, 397^{* *}\right)$

Optimism: Neuroticism $\left(r=-, 481^{* *}\right)$, Conformity $\left(r=-, 311^{*}\right)$, age $\left(r=-, 300^{*}\right)$

As a general conclusion of adaptation process of PsyCap Questionnaire, research results directed towards encouraging and guiding of usage of Armenian PCQ. Adoption of these directives for future research will contribute the perspective of improving the effectiveness of organizational studies, motivation, productivity and efficiency.

\section{References}

1. Chavush M., Kapusuz A., Psychological Capital: Definition, Components and Effects. British Journal of Education, Society \& Behavioural Science. 5. 2015, p. 244-255 DOI:10.9734/BJESBS/2015/12574

2. Lorenz T., Beer C., Puitz J., Heinitz K., Measuring Psychological Capital: Construction and Validation of the Compound PsyCap Scale (CPC-12). PLoS ONE 11(4) 2016: e0152892. https://doi.org/10.1371/journal.pone.0152892

3. Luthans, F., Youssef, C. M., \& Avolio, B. J. (2007). Psychological capital. New York: Oxford University Press, 240 p.

4. Matthews-Lopez J. L. Ph.D., Educational Research and Evaluation, Best practices and Technical Issues in Cross-Lingual, Cross-Cultural Assessments: An Evaluation of a Test Adaptation (232pp.), November, 2003, Director of Dissertation: George A. Johanson

5. Моросанова В. И., Аванесян Г. М., Ресурсный подход к психологическому капиталу и осознанной саморегуляции человека, Modern Psychology Scientific Bulletin 2020 \#1, стр. 88-99, DOI: https://doi.org/10.46991/SBMP/2020.3.1.088 
6. Моросанова, В. И. Стилевая саморегуляция поведения человека : научное издание / В.И. Моросанова, Е.М. Коноз // Вопр. психологии. 2000. - N 2. - C. 118-127.

7. Psychological Capital Questionnaire https://en.wikipedia.org/wiki/Psychological_Capital_Questionnaire\#cite_ref -5 , ujg' 15.06.21

\title{
АДАПТАЦИЯ И ВАЛИДАЦИЯ ВОПРОСНИКА ПСИХОЛОГИЧЕСКОГО КАПИТАЛА (РСQ) НА АРМЯНСКОМ ЯЗЫКЕ
}

\author{
Восканян К. В., Папоян С.А., Манукян М. А., Овсепян Н. С. (Ереванский \\ государственный университет, Ереван, Армения)
}

В статье представлены основные особенности процесса адаптации опросника психологического капитала (PCQ). Было проведено пилотное исследование для проверки надежности и валидности опросника среди населения Армении. Психологический капитал (РsyCap)-это личный ресурс, связанный с положительными индивидуальными и организационными характеристиками (производительность, благополучие, отношения и т. д.). В процессе пилотажного исследования проверялась связь между PsyCap и другими конструктами, такими как личностные черты Большой пятерки, саморегуляция (В. Моросанова), мотивация успеха (Т. Элерс) и система ценностей (Шварц). Результаты кореляционного анализа показали, что армянская версия опросника психологического капитала является надежным и действенным инструментом.

Ключевые слова: психологический капитал, адаптация, валидация, коррелячия, Армянская выборка.

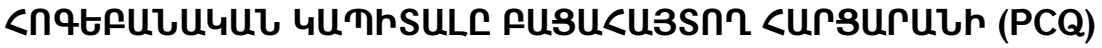

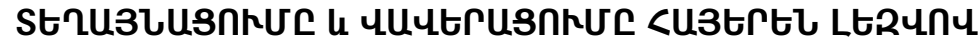

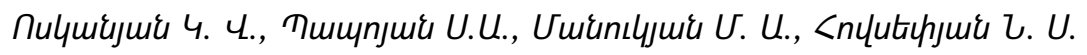

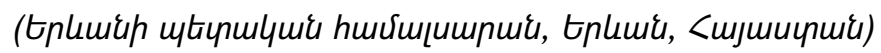

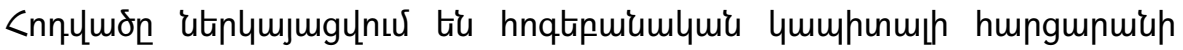

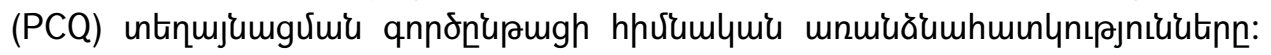

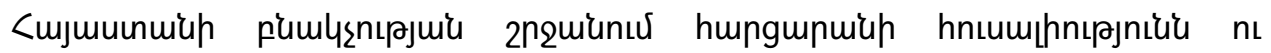

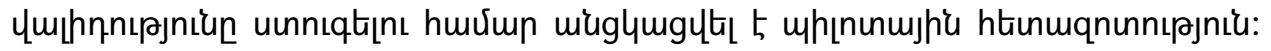

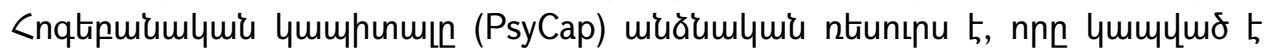

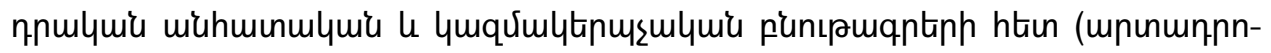

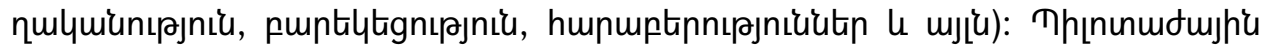




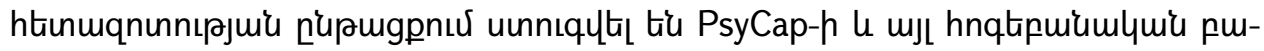

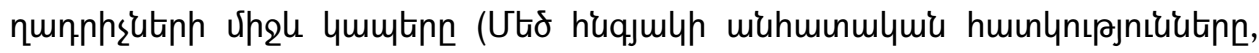

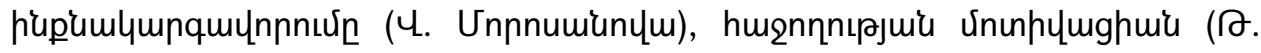

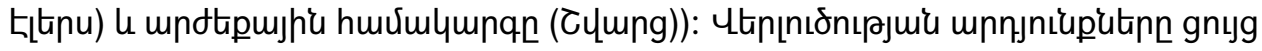

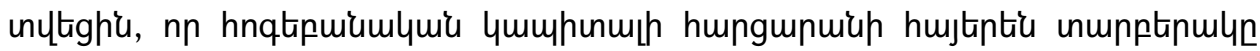

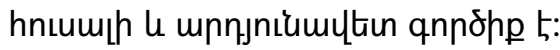

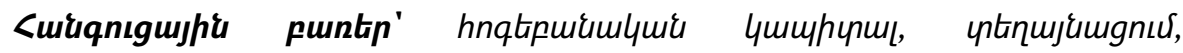

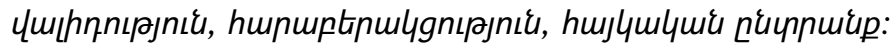

